\title{
Professional Development of Information Technology and Technical Education Teachers
}

\author{
Henryk Noga*
}

\begin{abstract}
Due to normal work duty and responsibilities, the responsibility for students' motivation and self-development motivates teachers for continuous training and thus to expand their own competencies. It is especially important in case of teachers who graduate technical and information technology (IT). IT teachers should be familiar with the latest technology as well as innovative solutions in the field of didactics of technical subjects.

This article concerns issues related to the professional development of information technology and technical education teachers in Poland. An analysis of documents shows the stages of professional development. It also highlights the requirements necessary to fulfill on different levels of a teacher's professional career.
\end{abstract}

Key words: teacher's career, teacher's development, education, teaching skills.

\section{Introduction}

Today's demands and the upcoming challenges result in growing expectations from teachers - on their ability to interpret and understand the processes taking place in the educational system of the country as well as worldwide trends. Teachers' professional development comes along with the duty of continuous improvement, gaining knowledge and mastering skills. Being a good teacher includes many features. Fulfilling the professional duties and responsibilities in order to meet the students' educational needs require patience, wide knowledge, teaching and communication skills and a variety of pedagogical competencies. Continuous education of teachers is understood as an accessory of teacher candidates in improving their professional qualifications as a supplement to teacher training leading to gaining full professional qualifications; as providing teachers with proper knowledge and equip them with skills that expand their qualifications and go beyond it. Teachers' development is based on the parallel and interrelated evolution of both practical-moral and technical competencies.

\footnotetext{
*Henryk Noga, Pedagogical University in Cracow, Cracow, Poland; senoga@cyf-kr.edu.pl
} 


\section{Acta Technologica Dubnicae \\ volume 6, 2016, issue 2}

According to Czeslaw Banach (2009), teachers' development, their adaptability and innovativeness depend on their capabilities in various spheres of life - from the knowledge of education law to determination and participation in the decision making process concerning the functioning of a school.

Many publications, discussions, conferences on the teaching subject have been held and written already. Despite this, the problem is still relevant and present, often returns to the headlines of magazines and books, and is the subject of seminars and scientific conferences. There are many questions in the field of education that still need to be answered. What kind of competencies and features should characterize a contemporary teacher? How should teacher training look like? How to improve the skills of practicing teachers? How should their work proceed? What is, what can, and what should be the position of a teacher in the society and in the system of education? These are just some of the questions that regularly appear and have almost never received a clear, complete and final answer. General education of technical education teachers in Poland takes place mostly in universities and colleges. The existing model of training technical education teachers often does not take into account the specifics of the teachers' future work. This means that regardless of whether prospective teachers are willing to work in general or vocational education, the educational program and the obtained training are the same.

\section{Teachers' professional development}

Teachers should be interested in the development of their own skills and knowledge if their aim to influence and affect the development of their students. Therefore, a career plan is helpful. The career development of teachers is defined in legislation - art. 9a-9i Act of January 26, 1982 (Teachers' Charter with further amendments), and the Regulation of the Minister of National Education of 1 March 2013 on the professional promotion of teachers (Journal of Laws 2013, Item 393). Mastering skills by teachers is important, it is a part of the process of their personal development and a means of improving the quality of the institutions in which teachers are employed. Only teachers employed by institutions included in the system of education can be promoted.

The development of a teacher depends on many factors - motivation, mental, spiritual, etc., arises from the personal capabilities and various components of human personality.

Teachers' development means a positive change in the quality of educational competencies that truly support the education and the development of students, and above all, improve the personality of the teachers. 


\section{Acta Technologica Dubnicae \\ volume 6, 2016, issue 2}

It has to be underlined that teachers' professional development continues throughout their active participation in school education. Teachers' development is based on expanding their skills, competencies as well as general knowledge and knowledge form the fields of pedagogy and psychology. Professional development can be characterized by the four levels of professional promotion. According to the Teachers' Charter, teachers can obtain the following professional promotion grades:

- trainee teacher;

- contract teacher;

- appointed teacher;

- chartered teacher.

The four promotion grades are described below.

\section{Trainee teachers}

An internship is a time of preparation, in which freshly graduated teachers gain and develop knowledge, skills and experience needed for further promotion. A teacher willing to enter into an internship contract in a school does not submit an application to a headmaster of a school, his/her work begins with the beginning of the school year, but not later than 14 days from the date of commencement of classes. In the case of an employment relationship upon expiry of this deadline, the teacher cannot start the internship until the end of the year.

The headmaster of a school assigns a mentor teacher, which has to be at least a contract teacher. This mentor does not have to be a teacher of the same subject, but his/her experience in teaching and education is important, as well as his/her knowledge of the work in the school.

The task of the supervisor is to help the trainee teacher in the process of preparation and implementation of the development plan and to evaluate the project for the training period. The trainee teacher prepares a professional development plan which shall be submitted to the headmaster within 20 days from starting conducting classes. The headmaster has to accept or to return the professional development plan of a trainee teacher (with remarks for revision) within 30 days from the date of receiving it. If the plan is returned to the trainee teacher, he/she has to improve it and make some necessary changes according to the headmaster's suggestions. In this case, the teacher is obliged to improve the plan immediately and to re-submit it to the headmaster. A professional development plan should include: 


\section{Acta Technologica Dubnicae \\ volume 6, 2016, issue 2}

- the specifics and the needs of the school;

- activities to be performed (in accordance with the Regulation of the Minister of National Education of 1 March 2013 on the professional promotion of teachers) (Journal of Laws 2013, Item 393);

- knowledge, skills and experience the trainee teacher should develop.

After the "probation time" the teacher is obliged, within 30 days, to submit a report on the implementation of the individual skill development program to the headmaster, which may be in the following forms:

- records of completed tasks (analysis of own activities, assessment of their effectiveness, estimated adjustments, conclusions) in a dedicated notebook;

- lesson plans, children's works, etc.;

- a list of studied professional literature, certificates from participation in professional development forms.

The school's headmaster evaluates the teacher's professional achievements after the initial internship taking into account the degree of implementation of the plan of professional development. After receiving a positive assessment for the internship, the teacher has 14 days to submit an application to take the qualification procedure.

The application is submitted to the headmaster who appoints a selection committee from the teaching staff, which includes:

- the headmaster - as its chairman;

- a school subject specialist (educational), if there in not such in the school, another qualified employee of the school is appointed;

- a supervisor.

The date of the interview is set by the headmaster. The interview is conducted by the committee. The trainee teacher applying for promotion to the position of a contract teacher submits a report on the implementation of the plan of professional development and has to answer some questions asked by the committee.

\section{Contract teachers}

An internship starts at the beginning of the school year, but not later than 14 days from the beginning of the school year, at the request addressed to the headmaster of the school. The internship lasts for 2 years and 9 months. As in the case of trainee teachers, the school's headmaster assigns a tutor from among the appointed teachers. 


\section{Acta Technologica Dubnicae \\ volume 6, 2016, issue 2}

During the internship, contract teachers realize their own professional development plan, which should include:

- $\quad$ the specifics and the needs of the school;

- tasks to be undertaken by the teacher according to the Regulation of the Minister of National Education of 1 March 2013 on the professional promotion of teachers (Journal of Laws 2013, Item 393);

- requirements for the grade of the contract teacher;

- knowledge, skills and experience the teacher has to develop.

The teacher's professional development plan is presented to the headmaster of the school for approval. The headmaster approves the plan presented by the teacher within 30 days from the date of commencement of classes. During the apprenticeship, the most important tasks of a teacher are:

- participation in the work of school authorities related to the activities of education or other proceedings arising from the statute and the needs of the school;

- developing knowledge and skills;

- exploring the education law and the education system.

During the process of fulfilling the tasks included in the teacher's plan of development, the school's headmaster gathers information about their execution and the efficiency of classes conducted by the teacher.

After completion of the internship, within 30 days, the teacher works out a report on the implementation of the plan of professional development and submits it to the headmaster. The school's headmaster assesses the professional achievements for the period of the internship, taking into account the development plan, the tutor's evaluation of the project and the outcomes of the consultation with the parents' board. The headmaster of the school may also ask the student council for an opinion. The parents' board presents its opinion within 14 days after being asked to do so. The teacher, after obtaining a positive evaluation of professional achievements, may submit a request to resume the proceedings for the next grade to the authority of the school.

The application shall include:

- certified copies of documents confirming the applicant's professional qualifications;

- a certified copy of the teaching degree contract;

- the school headmaster's certificate containing information about the employment and the range of subjects that the teacher is supervising, the 


\section{Acta Technologica Dubnicae \\ volume 6, 2016, issue 2}

date of confirmation of the plan of professional development, the date of the report on the implementation of the plan of professional development, the candidate's professional achievements during the internship period and the date of issue.

\section{Appointed teachers}

A contract teacher can begin an internship for being promoted to an appointed teacher after working for two years after becoming a contract teacher. The teacher must submit a request to the school's headmaster, because the promotion to the next career stage is not automatic when the conditions are fulfilled. It may be that the teacher does not submit a request and remains at the same job position until the end of his/her teaching career. When applying for an internship, the teacher must submit the project of his/her development plan to the school's headmaster. As with the previous stages, during the internship, the teacher realizes his/her professional development plan approved by the school's headmaster. For the internship period, the teacher receives an evaluation of the professional achievements. After a positive evaluation, the teacher submits an application form to the governing authority of the school in order to begin the examination procedure. The governing authority of the school analyzes the application form and other documents submitted by the teacher. The analysis consists of checking whether the teacher has fulfilled all the requirements and submitted all the necessary documents. If the documentation is correct, the governing authority of the school appoints the examination committee which will conduct the exam.

\section{Chartered teachers}

An appointed teacher can start training for becoming a chartered teacher after working at a school for at least one year after the date of getting the last promotion. As in the cases mentioned above, professional training starts at the beginning, but not later than 14 days from the beginning of the particular school year. The teacher has no mentor at this level, but the headmaster approves the development plan and makes an assessment of the professional work the teacher has already done. The school's headmaster is also a member of the qualifying committee, that evaluates the candidate's fulfillment of the necessary requirements for becoming a chartered teacher.

\section{Job specification of technical education teachers}

\subsection{Vocational subject teachers}

The relationship between education and the economic life is a factor having an impact on the enormous diversity of the content of education, which is why 


\section{Acta Technologica Dubnicae \\ volume 6, 2016, issue 2}

general technical teachers form a very diverse group within the teachers' community. These differences relate inter alia:

- A number of subject teachers, after the completion of a certain field of study and the acquisition of skills, may teach a certain number of subjects. And so, graduate mechanical teacher receives permission to teach dozens of subjects in the curriculum of various kinds of mechanical professions. The situation is similar in the case of economic subjects, electricity - electronics, construction, etc.

- Types and forms of lessons, theory lessons, practical examinations, laboratory exercises, laboratory classes.

- The pace of changes in the content of education changes the content of teaching, especially when it comes to specialty items - these were taking place rapidly in comparison to other subjects.

From December 31, 1990 branches of teacher training were liquidated and their role in organizing teachers' training was taken by provincial pedagogical methodological centers and some universities. In 1991, pedagogical studies were converted into teaching courses. Regulation of the Minister of National Education of 5 March 1992 concerning teacher training (Journal of Laws 1992, Item 1152013) resolved pedagogical technical studies. These decisions significantly weakened the system of training vocational subject teachers because of the rapid economic development.

\subsection{General subject teachers}

A novice teacher obtains the position of a trainee teacher and begins to climb up the ladder of promotion from the internship. For the first year of work, a teacher becomes familiar with the work of school, gains the necessary experience. The internship starts automatically at the beginning of the school year, but no later than 14 days from September 1. If the teacher still has an established employment, he/she cannot begin the internship that school year. For the next 9 months, the teacher is a trainee teacher. When the internship begins, the headmaster assigns a mentor for the trainee teacher. The mentor has to be an appointed or a chartered teacher, but does not have to teach the same subject as the trainee teacher.

The next stage in a teacher's career is the position of a contract teacher who applies for the position of an appointed teacher. Then, he can start an internship as an appointed teacher, having worked at the school for at least two years from the day of conferment of the previous career stage. Similarly, as it is in the case of the previous stage, internship starts at the beginning of the school year, but no later than 14 days after it. But in this case, the contract teacher must submit a request to the headmaster of the school. This plan should take into consideration 


\section{Acta Technologica Dubnicae \\ volume 6, 2016, issue 2}

the specifics and the needs of a school and the requirements in accordance with the law regulation on promotion. Also, one should take into account his/her existing knowledge, skills and experience.

A chartered teacher with at least 20 years of teaching experience and after 10 years of employment as a chartered teacher, may receive the title of an honorary professor of education. This title is awarded at the request of the Chapter Affairs Professors of Education, the minister responsible for education. The teacher must also have a significant and acknowledged career. Applications to the Chapter should be submitted by the pedagogical supervisor.

\section{Conclusion}

Teaching is a profession that requires constant self-development and training. Because of many changes in education law, teachers in Poland have to be especially aware of these amendments and have to adjust their careers all the time. Technical and information technology teachers additionally have to be familiar with the latest technology as well as innovative solutions in the didactics of technical subjects.

\section{References}

Act of 26 January 1982 - The Teachers' Charter (with further amendments).

Andruszewicz, F., Barczyk, P. P. (2008). Specyfika kształcenia zawodowego w 46 reformującym się systemie edukacji. In A. Barczyk, P. P. Barczyk (Eds.), „Status prawno - organizacyjny $i$ pedagogiczny szkolnych nierasowych środowisk wychowawczych “. Mysłowice: Oficyna Wydawnicza „Impuls“.

Hudec, M., Feszterová, M., \& Noga, H. (2016). Statistic methods for evaluating the content of humus in soil, based on environmental and ecological relationships. In APLIMAT 2016 - 15th Conference on Applied Mathematics 2016 (pp. 518-526). Bratislava: STU.

Kozík, T., Noga, H., \& Depešová, J. (2015). The symptoms of postmodernism in media and multimedia. European Journal of Science and Theology, 11(6), 119-125.

Ochmański, M. (2009). Edukacja w perspektywie integracji Europy. In Cz. Banach, Nauczyciel naszych oczekiwań $i$ potrzeb od A do Ż. Lublin: Wydawnictwo WSEiI.

Regulation of the Minister of National Education of 1 March 2013 on the professional promotion of teachers (Journal of Laws 2013, Item 393).

Regulation of the Minister of National Education of 5 March 1992 on teacher training (Journal of Laws 1992, Item 1152013). 


\section{Acta Technologica Dubnicae \\ volume 6, 2016, issue 2}

Walat, W. (2014). Cognitive theories of learning as the basis for didactic metaprogramming. Informatologia, 47(2-3), 145-149.

Walat, W. (2010). Necessity of education changes under developing information and communication technologies (ICT). Informatologia, 43(2), 116-121. 